\title{
Methods of integrated assessment of professionally important socio-psychological characteristics of a specialist in pharmacy as a component of the creation of a patient-centered space
}

\author{
M. I. Harkusha, O. I. Tykhonov, R. V. Sahaidak-Nikitiuk*, N. V. Demchenko, O. S. Shpychak \\ National University of Pharmacy, Kharkiv, Ukraine
}

The article proposes a method for evaluating professionally important socio-psychological characteristics of a pharmacy specialist. To determine the level of development of socio-psychological characteristics, the feasibility of using integrated and integral indicators has been proved.

Materials and methods. To achieve the goal set in the study, the following methods were used: the method of generalization, grouping and logical analysis, economic and mathematical methods, namely the taxonomy method, which was used to calculate the complex social and psychological components of the level of development of professionally important characteristics of pharmacy specialists and their integral magnitude. The expert method was used to determine the components that make up the professionally important sociopsychological characteristics of pharmacy specialists.

The opinion of the respondents is justified, as evidenced by the concordance coefficient exceeding the established threshold value $(0.75)$ and the Pearson criterion (the calculated value of which is higher than the table value taking into account the number of degrees of freedom). 995 pharmacy specialists from all regions of Ukraine participated in the survey.

Testing was used to assess the level of development of professionally important social and psychological characteristics of pharmacy specialists.

Results. On the basis of the conducted studies, it was proved that the complex indicator of the level of development of professionally important psychological qualities of a pharmacy specialist should include indicators of his psycho-emotional stability, volitional, moral and intellectual qualities.

A comprehensive indicator of the level of development of professionally important social qualities of a pharmacy specialist should include indicators of the level of his personal attitude, attitude towards people and work. The indicators included in the listed qualities were determined using the weighted average rank of each component and the level of development of the corresponding qualities determined on the basis of testing by pharmacy specialists. Then, using the taxonomic method, the integral indicator of the level of development of professionally important socio-psychological characteristics was calculated, depending on the size of which the pharmacists were divided into three groups. And on the basis of the separation of pharmacy specialists, the development of directions for the development or improvement of their professionally important socio-psychological characteristics is carried out.

Conclusions. The expediency of using complex and integral indicators for assessing the level of development of professionally important socio-psychological characteristics of pharmacists, calculated using the taxonomic method, has been proved.

Методика інтегрального оцінювання професійно важливих соціально-психологічних характеристик фахівця фармації як складової створення пацієнтоцентричного простору

М. І. Гаркуша, О. І. Тихонов, Р. В. Сагайдак-Нікітюк, Н. В. Демченко, О. С. Шпичак

Мета роботи - запропонувати методику оцінювання професійно важливих соціально-психологічних характеристик фахівця фармації; довести доцільність використання інтегрованих та інтегральних показників для визначення рівня розвитку соціально-психологічних характеристик.

Матеріали та методи. Для досягнення мети застосовували методи узагальнення, групування, логічного аналізу, економіко-математичні методи, як-от метод таксономії, за допомогою якого розраховували комплексні величини соціальної та психологічної складової рівня розвитку професійно важливих характеристик фахівців фрармації та їхню інтегральну величину. Експертний метод використовували для визначення складових, які входять до складу професійно важливих соціально-психологічних характеристик фахівців фармації. Висновки респондентів є обґрунтованими, що доведено коефіцієнтом конкордації, який перевищує встановлене порогове значення $(0,75)$, та критерієм Пірсона (розрахункова величина критерію вища за табличне значення, яке враховує число ступенів свободи). В опитуванні взяли участь 995 фахівців фармації з усіх регіонів України.

ARTICLE

INFO

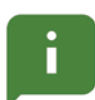

http:l/pharmed.

zsmu.edu.ualarticle

view/159147
UDC: $615.014 \cdot 2 \cdot 615.453 \cdot 615.214 .2$

DOI: 10.14739/2409-2932.2019.1.159147

Current issues in pharmacy and medicine: science and practice 2019; 12 (1), 78-83

Key words: evaluation research, professionalism, pharmacist, social psychology.

E-mail: sagaidak_rita@ukr.net

Received: 08.01.2019 // Revised: 16.01.2019 // Accepted: 21.01.2019 
Тестування застосовували для оцінювання рівня розвитку професійно важливих соціальних і психологічних характеристик фахівців фармації.

Результати. Визначили, що до складу комплексного показника рівня розвитку професійно важливих психологічних якостей фахівця фрармації повинні входити показники його психоемоційної стійкості, вольових, моральних та інтелектуальних якостей. Комплексний показник рівня розвитку професійно важливих соціальних якостей фрахівця фармації повинен містити показники рівня його особистісного ставлення, ставлення до людей та справи. Показники, що входять до складу перерахованих якостей, визначили за допомогою середньозваженого рангу кожної складової та рівня розвитку відповідних якостей, визначених на підставі тестування фрахівців фрармації. Потім за допомогою таксономічного методу розрахували інтегральний показник рівня розвитку професійно важливих соціально-психологічних характеристик та залежно від його величини ділили фрахівців фрармації на 3 групи. На підставі поділу фахівців фармації визначили напрями розвитку чи удосконалення їхніх професійно важливих соціально-психологічних характеристик.

Висновки. Доведена доцільність застосування комплексних та інтегрального показників оцінювання рівня розвитку професійно важливих соціально-психологічних характеристик фахівців фармації, які визначили за допомогою таксономічного методу.

Ключові слова: оціночні дослідження, професіоналізм, фармацевт, соціальна психологія.

Актуальні питання фрармацевтичної і медичної науки та практики. - 2019. - Т. 12, № 1(29). - С. 78-83

\section{Методика интегральной оценки профессионально важных социально-психологических характеристик специалиста фармации как составной создания пациентоцентричного пространства}

\section{М. И. Гаркуша, А. И. Тихонов, Р. В. Сагайдак-Никитюк, Н. В. Демченко, О. С. Шпичак}

Цель работы - предложить методику оценки профессионально важных социально-психологических характеристик специалиста фрармации; показать целесообразность использования интегральных и интегрированных показателей для определения уровня развития социально-психологических характеристик.

Материалы и методы. Для достижения цели применяли методы обобщения, группировки и логического анализа, экономико-математические методы, а именно метод таксономии, с помощью которого рассчитывали комплексные величины социальной и психологической составляющих уровня развития профессионально важных характеристик специалистов фрармации и их интегральную величину. Экспертный метод использовали для определения составляющих, входящих в состав профессионально важных социально-психологических характеристик специалистов фрармации. Мнение респондентов является обоснованным, что доказано коэффициентом конкордации, превышающим установленное пороговое значение $(0,75)$, и критерием Пирсона (расчетная величина которого выше табличного значения, учитывающего число степеней свободы). В опросе участвовали 995 специалистов фармации со всех регионов Украины.

Тестирование использовали для оценки уровня развития профессионально важных социальных и психологических характеристик специалистов фрармации.

Результаты. На основании проведенных исследований показано, что в состав комплексного показателя уровня развития профессионально важных психологических качеств специалиста фармации должны входить показатели его психоэмоциональной устойчивости, волевых, нравственных и интеллектуальных качеств. Комплексный показатель уровня развития профессионально важных социальных качеств специалиста фрармации должен включать показатели уровня его личностного отношения, отношение к людям и делу. Показатели, входящие в состав перечисленных качеств, определили с помощью средневзвешенного ранга каждой составляющей и уровня развития соответствующих качеств, определенных на основании тестирования специалистов фармации. Затем с помощью таксономического метода рассчитали интегральный показатель уровня развития профессионально важных социально-психологических характеристик, в зависимости от величины которого провизоров поделили на 3 группы. На основании разделения специалистов фармации определены направления развития или совершенствования их профессионально важных социально-психологических характеристик.

Выводы. Доказана целесообразность применения комплексных и интегрального показателей оценки уровня развития профессионально важных социально-психологических характеристик провизоров, рассчитываемых с помощью таксономического метода.

Ключевые слова: оценочные исследования, профессионализм, фрармацевт, социальная психология.

Актуальные вопросы фармацевтической и медицинской науки и практики. - 2019. - Т. 12, № 1(29). - С. 78-83

Professional activities of pharmacy professionals are multifaceted and require the knowledge, skills and abilities. At the same time, professionalism is achieved not only by the level of education obtained at a higher education institution and work experience but also by his desire for professional and career advancement. On the other hand, such factors as a new economic condition, the rapid development of pharmacy, constant software updates and a number of other factors due to market relations require the pharmacy specialist new knowledge not only in the field of pharmacology and pharmacy, but also in the field of modern information technologies, as well as possession sales skills, communication and conflict resolution.

The study of regulatory documents in the field of pharmacy has made it possible to determine that the current professional duties of pharmacists are the effective counselling of pharmacy visitors and the medicinal products management (reception, storage, placement on windows, vacations, etc.). But according to modern tendencies, their main task is to provide assistance for patients, visitor orientation [1-2]. The analysis of the requirements of stakeholders to applicants for a pharmacy 
specialist highlighted that, in addition to professional skills, level of education and a certain area of knowledge, they pay particular attention to the personal characteristics of a pharmacy specialist [3-13]. Because the client in obtaining the full satisfaction of both pharmaceutical and non-pecuniary, will visit only certain pharmacy. In addition, he wants to be heard and receive advice and sympathy. This, ultimately, will lead to an increase in the number of visits to the pharmacy institution by the population, and, accordingly, their profit.

Today, despite the high demands of the market and the increasing demands of pharmacy visitors, in the scientific literature [14-18] there are still no comprehensive studies assessing the professionally important socio-psychological characteristics (SPC) of a pharmacy specialist. That requires the intensification of research on this issue, taking into account the experience of the leading countries of the world in order to build a patient-centered space in a pharmacy.

\section{Aim}

The purpose of the article is to study the methodology for assessing the socio-psychological characteristics of pharmacists.

\section{Main research material (methods and objects) with the justification of the results}

Important for the professional activities SPC of pharmacy specialists manifest themselves through the ability to control their social behavior and understand the behavior of others, determine the mechanism for the occurrence of conflict situations and their prevention or settlement, own mechanisms of self-regulation, and the like $[19,20]$. Based on the survey conducted by pharmacy specialists, it was determined that they should be divided into two components, namely, psychological and social. For each of the components, it is advisable to calculate the complex values on the basis of which the integral indicator is calculated. These values will make it possible to generalize the level of professionally important SPC pharmacy specialists. A comprehensive indicator of the level of development of psychological skills of a pharmacy specialist has the form:

$$
K^{\text {psych skills }}=f\left(K_{\text {psycho-emot }} ; K_{\text {volitional }} ; K_{\text {moral }} ; K_{\text {in }}\right) \text {, }
$$

$K_{\text {psycho-emot }}$ : an indicator of the psycho-emotional stability level of a pharmacy psycho-emot
specialist;

$K_{\text {volitional }}$ indicator of level of volitional qualities of a pharmacy specialist; $K_{\text {moral: }}$ an indicator of the level of moral qualities of a pharmacy specialist;

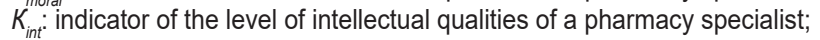

Complex indicator of the level of development of social skills of a pharmacy specialist:

$$
K^{\text {social skills }}=f\left(K_{\text {personal attit }} ; K_{\text {attitpeople }} ; K_{\text {attit busin }}\right) \text {, }
$$

$K_{\text {personal attiti }}$ indicator of the level of personal attitude of the pharmacy specialist;

$K_{\text {attit.people }}$ : indicator of the attitude of the pharmacy specialist to people; $K_{\text {attit busin }}^{\text {attipeople }}$ indicator of pharmacy professional attitude to business.

Indicators that are part of the psychological and social skills of a pharmacy specialist were determined using the weighted average rank $\left(k_{\mathrm{Xi}}\right)$ of each component and the level of the corresponding skills determined on the basis of testing by pharmacy specialists. So, for the psychological skills of a pharmacy specialist, the components are equal: psychoemotional stability -8.3 , volitional qualities -6.4 , moral qualities- 7.5, intellectual (connative) qualities -7.8 . The weighted average rank of the component of social skills of a pharmacy specialist: personal attitude -5.4 , attitude to people -8.1 , attitude to work -7.2 . The ranking of the weighted average rank of the components of the pharmacy specialist $\operatorname{SPC}\left(k_{\mathrm{Xi}}\right)$ in descending order, constructed using the Statistica 12.0 program, is shown in Fig. 1.

Then we calculated weight coefficients for the $i$-th components of the psychological component $\left(\alpha_{\mathrm{i}}\left(k_{\mathrm{Xi}}\right)\right)$ : psycho-emotional stability -0.28 ; volitional qualities -0.21 ;

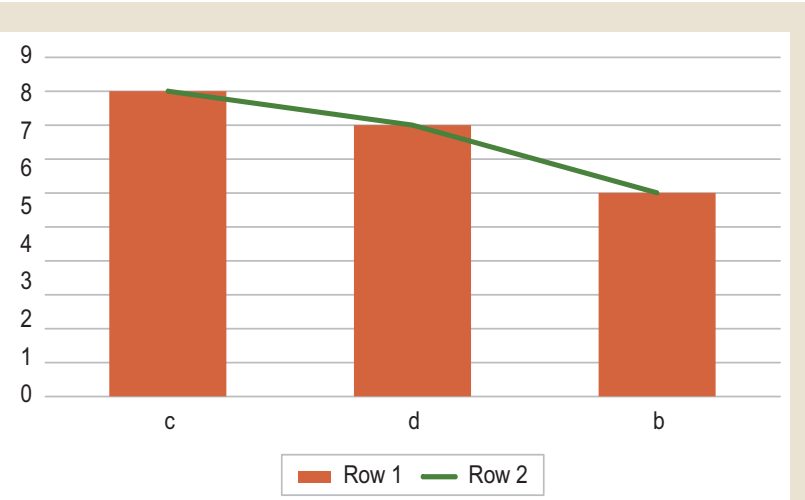

where the average weighted rank of the i-th component of the social skills of a pharmacy specialist:

b: personal attitude; c: attitude towards people; $\mathbf{d}$ : attitude to the case skills of a pharmacy specialist by components:

$\mathbf{x}$ : by psycho-emotional stability; $\mathbf{y}$ : by volitional qualities; $\mathbf{z}$ : by moral qualities; g: on intellectual qualities

Fig. 1. Histogram of the distribution of the weighted average ranks of the components of SPC pharmacy specialists. 
moral qualities -0.25 ; intellectual qualities -0.26 . Thus, all indicators that are part of the first component were assigned a weight factor of $0.07(0.28: 4)$, the second component -0.07 , the third component -0.0625 , the fourth component -0.052 .

The coefficients of weighting for the i-th components of the social component $\left(\alpha_{\mathrm{i}}\left(k_{\mathrm{Xi}}\right)\right)$ are: personal attitude -0.18 , attitude towards people -0.27 , attitude to the case -0.24 .
Accordingly, all the indicators that are part of the first component, assigned a weighting factor of 0.045 , the second component -0.09 , the third component -0.08 .

The results of calculating the level of development of the components of the social and psychological skills of pharmacy specialists for pharmacies A, B and C (including confidentiality) are given in Table 1.

Table 1. Results of the calculation of the level of development of social and psychological components of professionally important SPC pharmacy specialists

\begin{tabular}{|c|c|c|c|c|c|c|c|}
\hline \multirow{2}{*}{$\begin{array}{l}\text { Specialist } \\
\text { in pharmacy }\end{array}$} & \multicolumn{4}{|l|}{ Psychological skills } & \multicolumn{3}{|l|}{ Social skills } \\
\hline & emotional stability & volitional & moral & intellectual & personal attitude & attitude to people & attitude to business \\
\hline \multicolumn{8}{|c|}{ Pharmacy «A» } \\
\hline $\mathrm{A} 1$ & 0.14 & 0.21 & 0.15625 & 0.1092 & 0.081 & 0.171 & 0.2 \\
\hline $\mathrm{A} 2$ & 0.154 & 0.175 & 0.15 & 0.104 & 0.09 & 0.18 & 0.16 \\
\hline A3 & 0.147 & 0.196 & 0.1625 & 0.1196 & 0.0945 & 0.27 & 0.168 \\
\hline A4 & 0.161 & 0.21 & 0.15 & 0.1092 & 0.1125 & 0.252 & 0.176 \\
\hline A5 & 0.14 & 0.217 & 0.15625 & 0.104 & 0,09 & 0.234 & 0.184 \\
\hline A6 & 0.14 & 0.203 & 0.1875 & 0.13 & 0.09 & 0.27 & 0.16 \\
\hline A7 & 0.168 & 0.224 & 0.18125 & 0.1352 & 0.117 & 0.279 & 0.16 \\
\hline A8 & 0.147 & 0.21 & 0.175 & 0.14248 & 0.0945 & 0.288 & 0.24 \\
\hline A9 & 0.175 & 0.21 & 0.15 & 0.13 & 0.108 & 0.297 & 0.24 \\
\hline $\mathrm{A} 10$ & 0.175 & 0.217 & 0.15625 & 0.156 & 0.09 & 0.27 & 0.248 \\
\hline \multicolumn{8}{|c|}{ Pharmacy «B» } \\
\hline B1 & 0.147 & 0.189 & 0.13125 & 0.1144 & 0.0945 & 0.225 & 0.168 \\
\hline B2 & 0.14 & 0.182 & 0.1375 & 0.1092 & 0.1035 & 0.189 & 0.184 \\
\hline B3 & 0.182 & 0.147 & 0.15625 & 0.13 & 0.099 & 0.234 & 0.208 \\
\hline B4 & 0.175 & 0.217 & 0.14375 & 0.1248 & 0.117 & 0.243 & 0.192 \\
\hline B5 & 0.147 & 0.21 & 0.15625 & 0.1196 & 0.0945 & 0.279 & 0.2 \\
\hline B6 & 0.14 & 0.189 & 0.18125 & 0.1092 & 0.1125 & 0.288 & 0.184 \\
\hline B7 & 0.196 & 0.217 & 0.16875 & 0.1456 & 0.108 & 0.27 & 0.168 \\
\hline B8 & 0.189 & 0.245 & 0.1875 & 0.1404 & 0.117 & 0.306 & 0.16 \\
\hline B9 & 0.168 & 0.217 & 0.19375 & 0.1248 & 0.1035 & 0.288 & 0.24 \\
\hline B10 & 0.203 & 0.224 & 0.1625 & 0.1196 & 0.0945 & 0.225 & 0.272 \\
\hline \multicolumn{8}{|c|}{ Pharmacy «C» } \\
\hline $\mathrm{C} 1$ & 0.224 & 0.224 & 0.19375 & 0.1664 & 0.1395 & 0.279 & 0.248 \\
\hline $\mathrm{C} 2$ & 0.224 & 0.217 & 0.15625 & 0.1664 & 0.135 & 0.288 & 0.256 \\
\hline C3 & 0.2177 & 0.175 & 0.14375 & 0.156 & 0.144 & 0.297 & 0.216 \\
\hline $\mathrm{C} 4$ & 0.21 & 0.147 & 0.16875 & 0.1248 & 0.1485 & 0.27 & 0.168 \\
\hline C5 & 0.196 & 0.203 & 0.15 & 0.1456 & 0.117 & 0.27 & 0.2 \\
\hline C6 & 0.203 & 0.14 & 0.13125 & 0.1508 & 0.108 & 0.279 & 0.224 \\
\hline $\mathrm{C7}$ & 0.21 & 0.182 & 0.125 & 0.156 & 0.1125 & 0.225 & 0.248 \\
\hline C8 & 0.224 & 0.147 & 0.1875 & 0.156 & 0.1305 & 0.234 & 0.24 \\
\hline C9 & 0.189 & 0.189 & 0.2 & 0.13 & 0.1215 & 0.261 & 0.152 \\
\hline $\mathrm{C} 10$ & 0.147 & 0.21 & 0.2125 & 0.1248 & 0.135 & 0.27 & 0.256 \\
\hline
\end{tabular}


The integral index of the professionally important SPC of pharmacy specialists $\left(K_{\mathrm{int}}{ }_{\mathrm{SPC}}\right)$ is calculated on the basis of taxonomic analysis using the following model:

$$
K_{\text {int }}{ }^{S P C}=f\left(K^{\text {psych skills }} ; K^{\text {social skills }}\right)
$$

$K^{\text {psych skills: }}$ a comprehensive indicator of the psychological component level of professionally important pharmacy specialists' SPC;

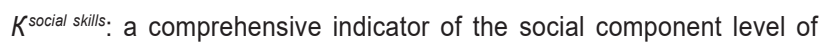
professionally important pharmacy specialists' SPC.

The magnitude of the level of development of the SPC experts pharmacy should be divided into certain groups. The analysis of the publications determined that the optimal separation of the zones of qualitative assessment of the integral indicator on the Cheddock scale, namely: group III - from 0 to 0.3 - a low level of development of SPC; Group II - from 0,31 to 0.65 - the average level of development of SPH; Group I - from 0.66 to 1.0 - a high level of SPC development.

The results of the calculation of the integrated and integral indicators of the level of development of professionally important SPC pharmacy specialists A, B and C and their zoning are shown in Table 2.

As a result of calculations, for the integral indicator of professionally important SPC specialists in pharmacy are divided as follows: for pharmacy $\mathrm{A}$ - pharmacist A3, A6; for pharmacy B - B6, B8, B10; for pharmacy C-C1, C3, C5, $\mathrm{C} 7, \mathrm{C} 9$. The third group includes: for the pharmacy $\mathrm{A}-\mathrm{A} 1$, A5, A7, A9; for pharmacy B - B1, B4, B7, B9; for pharmacy $\mathrm{C}-\mathrm{C} 2, \mathrm{C} 4, \mathrm{C} 6, \mathrm{C} 8, \mathrm{C} 10$.

Based on the division of specialists in pharmacy into groups, the directions of development or improvement of their SPC are determined. As an example of the directions of development of SPF specialists of pharmacy can lead training.

\section{Conclusions}

1. The relevance of the study of socio-psychological characteristics necessary for carrying out professional activity at the appropriate level is determined. It is proposed to share professionally important SPC specialists of pharmacy on the social and psychological component.

2 . To determine the level of development of socio-psychological characteristics, the feasibility of using integrated and integral indicators has been proved.

3. Complex indicators of the level of psychological and social qualities of the pharmacy specialist were determined using the weighted average of each component.

4. The integral indicator of professionally important socio-psychological characteristics of specialists in pharmacy is calculated using the taxonomic method.

Perspectives of further scientific research. Assessing the level of professionally important characteristics of a pharmacy specialist in the context of implementing European health legislation and implementing the requirements of good pharmacy practice, GPP will create patient-centered space in a pharmaceutical institution, which, in turn, will ensure an appropriate level of pharmaceutical care and support for
Table 2. Calculation results of integral and complex indicators of development of professionally important SPC specialists in pharmacy

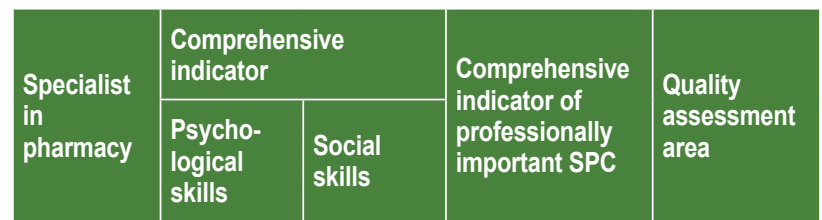

Pharmacy «A»

\begin{tabular}{|c|c|c|c|c|}
\hline A1 & 0.3345 & 0.4156 & 0.3750 & III \\
\hline A2 & 0.5234 & 0.4654 & 0.4444 & II \\
\hline A3 & 0.6012 & 0.7348 & 0.6680 & I \\
\hline A4 & 0.6145 & 0.6348 & 0.6246 & II \\
\hline A5 & 0.4478 & 0.4561 & 0.4519 & III \\
\hline A6 & 0.6892 & 0.7613 & 0.7252 & I \\
\hline A7 & 0.4026 & 0.3284 & 0.3655 & III \\
\hline A8 & 0.7015 & 0.5421 & 0.6218 & II \\
\hline A9 & 0.3123 & 0.3157 & 0.3640 & III \\
\hline A10 & 0.6987 & 0.6358 & 0.6672 & II \\
\hline \multicolumn{5}{|c|}{ Pharmacy «B» } \\
\hline B1 & 0.3987 & 0.3547 & 0.3267 & III \\
\hline B2 & 0.6248 & 0.6821 & 0.6534 & II \\
\hline B3 & 0.6871 & 0.5064 & 0.5967 & II \\
\hline B4 & 0.3547 & 0.4237 & 0.3392 & III \\
\hline B5 & 0.6235 & 0.6034 & 0.6134 & II \\
\hline B6 & 0.7025 & 0.7891 & 0.7458 & I \\
\hline B7 & 0.4712 & 0.4184 & 0.4648 & III \\
\hline B8 & 0.7231 & 0.6590 & 0.6910 & 1 \\
\hline B9 & 0.3357 & 0.3704 & 0.3530 & III \\
\hline B10 & 0.6488 & 0.6999 & 0.6743 & 1 \\
\hline
\end{tabular}

Pharmacy «C»

\begin{tabular}{|l|l|l|l|l|}
\hline C1 & 0.8405 & 0.6547 & 0.7476 & I \\
\hline C2 & 0.3321 & 0.3982 & 0.3651 & III \\
\hline C3 & 0.8964 & 0.7258 & 0.8111 & I \\
\hline C4 & 0.3013 & 0.4648 & 0.4330 & III \\
\hline C5 & 0.7821 & 0.8256 & 0.8038 & I \\
\hline C6 & 0.4736 & 0.4961 & 0.4848 & III \\
\hline C7 & 0.7089 & 0.9011 & 0.8050 & I \\
\hline C8 & 0.5789 & 0.3003 & 0.4396 & III \\
\hline C9 & 0.7254 & 0.8945 & 0.8099 & I \\
\hline C10 & 0.4935 & 0.5865 & 0.4900 & III \\
\hline
\end{tabular}


the institution's competitiveness. Based on the assessed level of professionally important characteristics, it is proposed to develop appropriate training programs in relation to raising the level of the studied characteristics or preventing professional deformation of $\mathrm{ph}$ armacy specialists.

Conflicts of interest: authors have no conflict of interest to declare. Конфлікт інтересів: відсутній.

Information about authors:

Harkusha M. I., Aspirant of the Department of Processes and Apparatuses of Chemical and Pharmaceutical Industries, National University of Pharmacy, Kharkiv, Ukraine.

ORCID ID: 0000-0003-1266-4587

Tykhonov O. I. , Laureate of the State Prize of Ukraine in the field of science and technology, Honored Worker of Science and Technology of Ukraine, Academician of the Ukrainian Academy of Sciences, Dr.hab., Professor of the Department of Technology of Perfumes and Cosmetics, National University of Pharmacy, Kharkiv, Ukraine.

ORCID ID: 000-0001-8895-1385

Sahaidak-Nikitiuk R. V., Dr.hab., Head of the Department of Processes and Apparatuses of Chemical and Pharmaceutical Industries, National University of Pharmacy, Kharkiv, Ukraine.

ORCID ID: 0000-0002-9337-7741

Demchenko N. V., PhD, Associate Professor of the Department of Management and Administration, National University of Pharmacy, Kharkiv, Ukraine.

ORCID ID: 0000-0001-5915-0087

Shpychak O. S., Dr.hab., Professor of the Drug Technology Department named after D.P. Salo, National University of Pharmacy, Kharkiv, Ukraine. ORCID ID: 0000-0002-3015-8584

Відомості про авторів:

Гаркуша М. І., аспірант каф. процесів та апаратів хімікофармацевтичних виробництв, Національний фармацевтичний університет, м. Харків, Україна.

Тихонов О. І. , Лауреат Державної премії України в галузі науки і техніки, заслужений діяч науки і техніки України, академік Української АН, д-р фрарм. наук, профресор каф. косметології і аромології, Національний фрармацевтичний університет, м. Харків, Україна Сагайдак-Нікітюк Р. В., д-р фарм. наук, зав. каф. процесів та апаратів хіміко-фармацевтичних виробництв, Національний фрармацевтичний університет, м. Харків, Україна.

Демченко Н. В., канд. економ. наук, доцент каф. менеджменту і адміністрування, Національний фармацевтичний університет, м. Харків, Україна.

Шпичак О. С., д-р фарм. наук, професор каф. аптечної технології ліків імені Д. П. Сала, Національний фармацевтичний університет, м. Харків, Україна.

Сведения об авторах:

Гаркуша М. И., аспирант каф. процессов и аппаратов химикофармацевтических производств, Национальный фармацевтический университет, г. Харьков, Украина.
Тихонов О. И., Лауреат Государственной премии Украины

в области науки и техники, заслуженный деятель науки и техники Украины, академик Украинской АН, д-р фарм. наук, профессор каф. косметологии и аромологии, Национальный фармацевтический университет, г. Харьков, Украина.

Сагайдак-Никитюк Р. В., д-р фарм. наук, зав. каф. процессов и аппаратов химико-фрармацевтических производств, Национальный фармацевтический университет, г. Харьков, Украина.

Демченко Н. В., канд. эконом. наук, доцент каф. менеджмента и администрирования, Национальный фармацевтический университет, г. Харьков, Украина.

Шпичак О. С., д-р фарм. наук, профессор каф. аптечной технологии лекарств, Национальный фармацевтический университет, г. Харьков, Украина.

\section{References}

[1] GPP Nalezhna aptechna praktyka: Standarty yakosti aptechnykh posluh: spilna nastanova MFF/VOOZzNAP [GPP Good Pharmacy Practice: Quality Standards for Pharmacy] (n.d.). Retrieved from http:// zakon5.rada.gov.ua/laws/show/897_009 [in Ukrainian].

[2] Daijob.com - Looking for jobs in Japan? Want to work in Japan? Retrieved from https://www.daijob.com

[3] Job search on jobs.ch, the leading online job portal on the Swiss market. Retrieved from http://www.jobs.ch/en/vacancies

[4] Denmark. Retrieved from http://denmark.dk

[5] Indeed official website. Retrieved from http://de.indeed.com

[6] Jobsite official website. Retrieved from http://www.jobsite.co.uk

[7] Job active. Powered by Job Search. Australian Government. Retrieved from https://jobsearch.gov.au/job

[8] Rabota $\vee$ Litve [Work in Lithuania official website]. Retrieved from http://www.cvonline.It/darbo-skelbimai/sveikatos-apsauga-socialine-rupyba\#JobAds

[9] Rabota v Latvii [Work in Latvia official website]. Retrieved from http:// eurabota.com/in/latvia/

[10] Rabota v E'stonii [Work in Estonia official website]. Retrieved from https://esn.org/

[11] Sait poiska raboty №1 v Ukraine [Site of job search №1 in Ukraine]. Retrieved from https://www.work.ual [in Ukrainian].

[12] Sajt poiska raboty v Ukraine [Site search job in Ukraine]. Retrieved from https://www.rabota.ua [in Ukrainian].

[13] Sajt poiska raboty v Ukraine [Site search job in Ukraine]. Retrieved from https://www.ua.trud.com/ [in Ukrainian].

[14] Sajt poiska raboty v Ukraine [Site of job search in Ukraine]. Retrieved from https://www.job.i.ua [in Ukrainian].

[15] Sait doslidnytskoho tsentru Mizhnarodnoho kadrovoho portalu hh.ua [Site of the research center of the International Staff Portal]. Retrieved from https://www.hh.ua/ [in Ukrainian].

[16] Altunina, I. R., \& Nemova, R. S. (2011). Social'na psikhologiya [Social psychology]. Moscow. [in Russian].

[17] Orban-Lembryk, L. E. (2004). Sotsialna psykholohiia [Social psychology]. Kyiv: Lybid [in Ukrainian].

[18] Solov'ev, S. V. (2012). Kadrovye tekhnologii [Personnel technologies]. Kyiv: Multimedijnoe izdatel'stvo Strel'bickogo [in Ukrainian].

[19] Zeer, E. F. (2003). Psikhologiya professij [Psychology of the professions]. Moscow: Akademicheskij Proekt; Ekaterinburg: Delovaya kniga. [in Russian]

[20] Bodrov, V. A. (2001). Psikhologiya professional'noj prigodnosti [Psychology of professional fitness]. Moscow. [in Russian]. 